\title{
Morphological Awareness of 3rd Grade School-Aged Children at Risk of Vocabulary Development
}

\author{
Kyunghee Jung \\ Department of Speech and Language Pathology, Graduate School of Rehabilitation and Welfare, Yongin University, Yongin, Korea
}

Correspondence: Kyunghee Jung, $\mathrm{PhD}$ Department of Speech Language Rehabilitation, Yongin University, 134 Yongindaehak-ro, Cheoingu, Yongin 17092, Korea

Tel: + 82-31-8020-2864

Fax: +82-31-8020-3075

E-mail: 1012jkh@hanmail.net

Received: April 4, 2020

Revised: April 30, 2020

Accepted: April 30, 2020

This article was supported by Nationl Research Foundation of Korea (NRF-2017S1A5A8021586).

\begin{abstract}
Objectives: This study aimed to examine the morphological awareness of school-age children in relation to the level of vocabulary development. Methods: The subjects of the study were 14 children in the at risk group of vocabulary development delay in the 3rd grade of elementary school, and 14 children who matched these children in chronological age and vocabulary level. A total of 42 children participated in the study. This studu used the task of morphological awareness developed based on the previous research, considering the type of words (cmpound and derivative) and transparency. Results: The results of the study are as follows: First, the total score of morphological awareness was significantly different between the three groups. There was no difference between the at-risk group and the children's group who were matched at the vocabulary level, but there was a significant difference between the groups with different vocabulary levels. Second, all three groups had low ability to perform tasks on derivatives. There was no significant difference between the vocabulary level matching group and the children in the vocabulary development delay group in the compound language task, but there was a significant difference in the derivative tasks. Third, there was a significant difference between the groups according to the transparency. The difference between the age-matched group and the other two groups was significant and the difference between the at-risk group and the vocabulary level match group was not significant. Conclusion: This result was suggested that the relationship with morphological awareness in early vocabulary evaluation and intervention should be considered.
\end{abstract}

Keywords: Morphological awareness, Vocabulary, Compound, Derivative, Transparency
학습을 위한 읽기 단계로 접어드는 초등 3학년 이후 아동들은 텍스트를 통해 수많은 어휘에 노출된다(Chall, 1983). 초등 2학년의 경우 평균 6,000 여개의 어근 단어를 이해하고, 6 학년까지 10,000 여 개의 어휘를 습득해야 한다(Anglin, 1993). 학령기의 어휘지식은 읽기 쓰기 발달의 기초 역할을 하고, 궁극적으로 학업 성취에도 중 요하다. 어휘지식이 풍부할수록 텍스트를 더 잘 이해할 수 있고, 읽 기이해능력이 우수할수록 더 많은 어휘를 배울 수 있게 된다(Stanovich, 2009). 학령기 아동의 어휘량에 있어서의 개인차는 상당히 크며, 어휘지식은 새 단어 학습을 촉진하는데 영향을 미친다는 면 에서 학년이 올라갈수록 그 차이는 점점 벌어질 가능성이 크다. 이 렇듯 학령기 동안 매년 수천 개의 어휘를 습득하지만 교육과정을
통해서는 이 중 약 $10 \%$ 정도만 명시적으로 배우게 되고, 텍스트를 통해 만나는 수천개의 단어 중 $15 \%-55 \%$ 는 모르는 단어이다(Nagy, Herman, \& Anderson, 1985).

학습에 필요한 수많은 어휘를 습득하기 위해서는 다양한 읽기 환경에 노출되어야 할 뿐 아니라 개별 단어를 명시적으로 지도해야 하지만 무엇보다 단어에 대한 인식능력을 높이고 단어의 의미를 해 결하는 전략을 적용할 수 있도록 지원하는 것이 중요하다(Farsi, 2008). 새로운 단어를 접한 아동들이 단어의 의미를 이해하기 위해 서는 어휘사전(mental lexicon)에 접근해야 한다. 어휘사전에 접근 하는 과정에서 형태소 단위의 작동 방식을 설명하는 몇 가지 모델 이 있다(Chialant \& Caramazza, 1995). 첫째 모델은 총체적 단어 
가설(whole-word hypothesis)로 이 가설에 의하면 단어는 단일어 나 복합어 등과 같은 단어를 구성하는 형태소의 복잡도나, 처리과 정의 차이 없이 단어 전체가 어휘사전에 등록된다. 두 번째 가설은 완전 분리 표상 가설(fully decomposed representation)인데 복합 어의 어근과 접사같은 형태소 단위가 각각 독립적으로 어휘사전에 표상된다고 주장한다. 세 번째 가설은 텍스트에서 만나는 단어의 철자 정보를 처리한 후 아는 단어의 경우는 총체적으로 처리하고 비친숙한 단어는 분리 처리하여 어휘사전에 접근한다는 확장 설명 된 형태론 모델(augmented address morphology)이다. 마지막은 계 산 모델인데(computational model), 이 모델에 의하면 텍스트에서 만나는 단어는 먼저 전체단어를 형태소 단위로 분절한 후 각 구성 요소들이 하위 의미범주나 구문규칙에 속하는지를 체크해서 처리 된다. 이러한 모델들은 모두 복합어가 어휘사전에 접근할 때 형태 론적 구조가 어떻게 영향을 미치는가를 공통적으로 설명해주고 있다. 즉, 학년이 올라갈수록 늘어나는 형태적으로 복잡한 어휘를 습득하는 과정에서 형태적 지식을 이용한 분석능력은 단어 의미해 결 과정에서 어휘사전으로의 접근에 영향을 미침으로써 어휘 성장 에 도움이 되고, 궁극적으로는 읽기 능력을 향상시키게 되는 것이 다. 본 연구는 어떤 모델이 어휘사전의 접근 방법을 더 잘 설명해주 는가를 규명하고자 하는데 목적을 두기보다 형태론적 분석 능력이 어휘 습득 능력과 밀접한 관련이 있다는 기본 가설에 근거하여 어 휘 습득 수준에 따른 형태소인식능력의 차이가 있는지를 규명하는 데 목적이 있다. 즉 형태소 단위의 분석 및 조작 능력이 우수한 아 동이 어휘능력이 우수할 것이라는 기본 가정을 검증함으로써 어휘 지도 전략에 대한 임상적 시사점을 살펴보고자 한다.

단어 의미에 대한 직접 교수는 어휘학습 증진에 효과적이지만 어휘 수준이 다른 아동들의 갭을 해결하는데는 제한점이 있어 중 재 시 좀더 전략적인 접근이 필요하다. 한편 학년이 올라갈수록 형 태적으로 내적 구조가 복잡한 복합어의 비중은 더 늘어나게 된다 (Nagy \& Anderson, 1984). 이러한 다형태소로 이루어진 복합어들 은 개별 성분의 구조를 분석하고, 개별 성분들의 의미를 통해 전체 의미를 예측할 수 있는 형태소인식능력을 통해 보다 효과적으로 학습될 수 있다(Wolter \& Green, 2013). 단어의 구성 성분을 분석 하고 이를 통해 새로운 의미를 추론해 내는 메타언어적 접근법으로 서의 형태소인식능력 중재는 어휘습득에 긍적적인 영향을 끼치는 것으로 많은 연구자들이 보고해 왔다(Apel, Diehm, \& Apel, 2013; Brimo, 2016; Ramirez, Walton, \& Roberts, 2014).

형태소인식능력은 상대적으로 일찍 발달이 시작되어 초등기 이 후까지 지속적으로 발달한다(Berko, 1958; Carisle, 2004). 형태소 인식능력의 발달을 추적한 Berninger, Abbott, Nagy 그리고 Carl- isle (2010)은 형태소인식능력이 1-3학년기까지 가장 가파른 성장을 보이는데, 그 이후로도 지속적으로 성장하며 중학년까지 이 기술 을 습득하지 못하면 중요한 중재 시기가 지연될 수 있다고 하였다 (Apel, Wilson-Fowler, Brimo, \& Perrin, 2012).

형태소인식능력은 단어를 효율적으로 사용하게 하는 메타언어 도구로서 언어와 문해 발달의 중요한 기술이며(Carlisle, 2000; Kirby et al., 2012; Scott \& Nagy, 2004), 형태소인식능력과 어휘 발달은 밀접히 관련되어 있다(Wagner, Muse, \& Tannenbaum, 2007). McBRIDE-CHANG, Wagner, Muse, Chow 그리고 Shu (2005)는 음운 인식, 단어재인 능력을 통제한 후에도 형태소인식능력이 아동의 어 휘지식의 $8 \%$ 를 설명해준다고 밝혔다. 또한 Wysocki와 Jenkins (1987)는 학령기 아동에게 어근 형태소의 의미를 가르친 후 이 어 근 형태소와 관련 있는 단어 정의하기를 관련 없는 단어보다 더 잘 수행했다는 것을 보여줬다. Ramirez 등(2013)은 유치원 아동의 어 휘수준에 따라 세 그룹(저, 중, 고)으로 나누고 세 달 동안 형태지식 기반 어휘 중재를 실시한 후 초등 1학년기에 어휘량을 측정하였다. 이 연구에 따르면 저수준 그룹과 고수준 그룹의 어휘 차이가 줄고, 저수준 그룹의 경우 중재 후 또래규준과 비교했을 때 유의한 차이 가 관찰되지 않아 중재 효과가 발달적 성숙의 효과 이상으로 큰 것 으로 해석하였다. Sparks와 Deacon (2012)은 초등 2학년 아동을 1 년간 종단적으로 추적한 연구를 통해서 초기 형태소인식능력이 후 기 어휘능력에 영향을 미친다고 보고하였다.

읽기는 어휘와 매우 밀접한 관련이 있기 때문에 어휘수준이 낮 은 아동들은 읽기수준도 낮은 경우가 많다(McBRIDE-CHANG et al., 2005). 2학년 말경 읽기 저성취 아이들은 중간성취 아이들에 비 해서는 약 2 년, 고성취 아이들에 비해서는 약 3 년 이상 어휘발달이 느리고(Biemiller \& Boote, 2006), 4학년이 되면 교과서에 비친숙한 단어들이 더욱 늘어나면서 읽기의 어려움을 겪게 되는데 이러한 어 휘 문제와 관련된 슬럼프 시기를 겪는다고 한다(Kim, 2013). 읽기 이해에 어려움이 있는 아동들은 다형태소가 포함된 복합어 과제에 대한 이해의 어려움이 있다. 형태소인식능력은 단어읽기를 통해 읽 기이해에 기여하거나 언어이해과정에서 형태소의 기능을 적용함 으로써 읽기이해에 직접적인 영향을 미친다(Mackay, Levesque, \& Deacon, 2017). 읽기이해부진 아동들은 파생복합어를 유추하는 과제와 형태분석과제 등에서 또래에 비해 수행력이 낮다는 연구를 통해 읽기이해부진 아동의 형태소인식 과제의 어려움이 보고되었 다(Mackay et al., 2017; Tong, Deacon, Kirby, Cain, \& Parrila, 2011). 일반 아동의 낱말 읽기 및 읽기이해능력을 형태소인식능력이 주 요하게 예측해주는 변인임을 밝힌 Jung (2014)의 연구를 비롯하여 최근 우리나라에서 읽기능력과 관련하여 형태소인식능력에 대한 
연구자들의 관심이 늘어나고 있지만 외국의 연구들과 달리 국내에 서 형태소인식능력을 읽기 및 어휘능력과 관련하여 탐구한 연구는 많지 않은 실정이다. 읽기학습 부진아동이나 다문화가정아동이 형 태소인식의 어려움이 있음을 보고한 연구(Kim, E., \& Jung, 2015;

Kim, S., \& Jung, 2015)가 보고 되었으나 어휘능력과 관련하여 살펴 본 연구는 부족하다. 어휘능력과 관련해서 형태소인식능력을 살펴 본 최근 연구로는 초등 1,2 학년 아동을 어휘 수준에 따라 하위, 중 위, 상위 어휘 집단으로 나눠 형태소인식능력이 차이가 나는지를 살펴본 Chung (2017)은 하위와 상위 어휘 집단 간 유의한 차이가 있음을 보고하였다. 또 다른 연구에서는 저학년과 중학년 모두 어 휘는 연결어미와 파생어 형태인식과 유의한 정적 상관관계가 있으 며, 어휘는 저학년의 연결어미 형태인식을 $4 \%$ 예측해 준다고 보고 하기도 하였다(Chung \& Shim, 2019). 하지만 또래 아동에 비해 어 휘능력발달이 느린 아동들이 어휘능력이 비슷한 더 어린 아동들 과 형태소인식 능력의 차이가 있는지에 대해서는 아직까지 연구자 의 관심을 받지 못하였다. 이 연구는 어휘능력이 비슷하지만 더 어 린 아동과 형태소인식능력을 비교하였을 때 차이가 나는지를 살펴 봄으로써 어휘능력과 형태소인식능력 간의 관계를 규명하고자 하 는 데 목적이 있다.

한편, 파생어 접사에 대한 인식능력이 어휘 및 읽기 발달과 상관 이 높음을 보고하고 있다(Carlisle, 2004; Kuo \& Anderson, 2006). 또한, 영어나 핀란드어 등에서는 굴절형태소가 중요하지만 중국어 는 상대적으로 굴절형태소가 덜 중요하며 어휘 합성이 더 일반적이 다(Bowers \& Kirby, 2010). 한국어 역시 중국어의 언어문화권을 상 당히 공유하고 있기 때문에 한자어의 영향을 받은 어휘의 수가 상 당하므로 합성어에 대한 고려가 필요하다. 본 연구에서는 어휘발달 지체 위험군 아동이 합성어와 파생어 유형에 따라 통제집단과 차 이가 있는지도 함께 살펴보았다. 또한 투명도는 얼마나 복합어 구 조 안에서 파생 형태소를 쉽게 분리해내거나 결합하여 새로운 단 어를 형성해 내는가와 관련이 있다. 투명도는 발달적으로 파생어 습득에 영향을 미치는 것으로 많은 연구들에서 보고되고 있고 (Carilsle, 2000; Kim, S., \& Jung, 2015), 이들 선행연구에서는 투명 도의 차이는 형태구조 지식의 적용과정에서 인지적 부담의 정도가 다르게 작용하게 된다는 점에서 발달적 차이에 기여하게 된다고 보 고하였는데 본 연구에서는 이러한 선행연구결과를 바탕으로 투명 도에 따른 집단적 차이를 살펴보고자 하였다. 이러한 연구목적을 구체화하기 위해 다음과 같은 연구문제를 설정하였다.

첫째, 초등 3 학년 어휘발달지체 위험군 아동은 어휘발달수준과 생활연령을 일치시킨 아동과 형태소인식능력의 차이가 있는가?

둘째, 단어유형(합성어, 파생어)에 따라 세 집단 간 형태소인식능
력은 차이가 있는가?

셋째, 투명도에 따라세 집단간 형태소인식능력은 차이가 있는가?

\section{연구방법}

\section{연구대상}

연구대상 아동은 초등학교 3학년 아동 중 어휘발달지체 위험군 아동 14 명, 이들과 생활연령을 일치시킨 아동 14 명, 어휘수준을 일 치시킨 아동 14 명, 총 42 명의 아동을 대상으로 하였다. 초등학교 3 학년 아동을 대상으로 한 이유는 선행연구에 의해 초등 3학년까지 형태소인식능력이 가파른 성장을 보이고 그 이후로도 완만한 성장 을 보인다는 Berninger 등(2010)의 선행연구 결과와 Chall (1983)의 읽기발달 단계 중 배우기 위해 읽는 단계로 접어드는 시기가 한국 교육과정에서 초등 3 학년 시기임을 고려하였다.

어휘발달지체 위험군 아동은 수용-표현어휘력검사(REVT; Kim, Hong, Kim, Jang, \& Lee, 2009)의 수용어휘 검사에서 $20 \%$ ile 미만 에 해당하는 초등학교 3 학년 아동이다. 생활연령일치 아동은 어휘 발달지체 위험군 아동과 생활월령 \pm 1 개월 이내의 아동을 일대일 매칭하여 구성하였다. 어휘수준일치 아동은 초등학교 1학년 아동 중 어휘발달지체 위험군 아동과 수용·표현어휘력검사의 수용어휘 획득 원점수 \pm 1 점 이내로 일대일 매칭한 아동으로 구성하였다. 세 집단 아동 모두 부모나 교사 등의 보고로 전반적 발달상의 어려움 이 없다고 보고된 아동이며, 한국어읽기검사(KOLRA; Pae, Kim, Yoon, \& Jahng, 2015)의 하위 항목인 낱말해독 검사에서 $25 \%$ ile 이 상으로 평가된 아동들로 구성하였다. 세 집단 아동의 월령, 어휘 및 낱말해독 검사 결과에 대한 통계검정 결과는 Table 1에 제시하였다.

\section{검사도구}

\section{대상자 선정도구}

연구에 참여한 초등 3 학년 아동과 어휘수준을 일치시킨 초등 1 학년 아동들에게는 단어읽기에 어려움이 없음을 확인하기 위해 한국어읽기검사(KOLRA; Pae et al., 2015)의 하위 항목인 낱말해 독 검사를 실시하였으며, 표준점수 85점 이상인 아동을 대상자로 선정하였다. 또한 어휘발달지체 위험군 아동과 어휘발달 수준을 일 치시킨 아동 집단을 구성하기 위해 수용·표현어휘력검사(REVT; Kim et al., 2009)를 실시하여 수용어휘 원점수로 일대일 매칭하였다.

\section{본 검사도구}

어휘검사도구

아동의 수용어휘량을 측정하기 위해 수용·표현어휘력검사 
Table 1. Characteristics of participants

\begin{tabular}{lclllll}
\hline & $\mathrm{VD}(\mathrm{N}=14)$ & $\mathrm{VA}(\mathrm{N}=14)$ & $\mathrm{CA}(\mathrm{N}=14)$ & Total $(\mathrm{N}=42)$ & $F$ & \multicolumn{1}{c}{ Scheffe } \\
\hline Age & $122.57(2.17)$ & $83.14(23.88)$ & $112.50(2.53)$ & $102.74(19.52)$ & $20.802^{*}$ & $\mathrm{VL}<\mathrm{VD}=\mathrm{CA}$ \\
REVT-R & $92.93(5.80)$ & $92.93(5.78)$ & $124.29(16.35)$ & $103.38(18.16)$ & $41.151^{*}$ & $\mathrm{VD}=\mathrm{VL}<\mathrm{CA}$ \\
Word decoding & $62.21(8.08)$ & $63.50(3.40)$ & $67.21(4.23)$ & $64.64(5.91)$ & 2.107 & \\
\hline
\end{tabular}

Values are presented as mean (SD).

$\mathrm{VD}=$ Vocabulary developmental Delay group; $\mathrm{CA}=$ Chronological Age matching group; $\mathrm{VL}=$ Vocabulary Level matching group; $\mathrm{REVT}-\mathrm{R}=$ Receptive \& Expressive Vocabulary Teat-Receptive (Kim et al., 2009).

${ }^{*} p<.05$.

(REVT; Kim et al., 2009)의 수용어휘 검사를 지침에 따라 실시하 여 산출된 원점수를 분석에 사용하였다.

형태소인식능력 검사도구

세 집단 아동의 형태소인식능력을 평가하기 위해서 Apel 등(2013) 의 연구를 바탕으로 단어의 유형(합성어, 파생어)과 투명도를 고려 하여 한국어 실정에 맞게 개발하여 적용했던 Jung (2014)의 형태소 인식과제를 사용하였다. 합성어 과제는 두 개의 어근을 결합하여 새 단어를 만들거나 보기 단어의 어근을 나눠서 그 중 하나의 어근 을 제시한 문장의 의미에 적합하게 빈칸에 삽입하도록 하였다. 문 항 수는 합성, 파생어 각 20 문항씩 총 40 문항으로 구성되어 있다. 또한, 이 40 개 항목 중 음운론적으로 투명한 단어와 불투명한 단어 가 각 20 문항씩 총 40 문항으로 구성되어 있다.

\section{연구절차 및 자료분석}

본 검사는 연구자를 포함하여 언어병리학을 전공하고 있는 대학 원생이 각 아동과 개별적으로 대면하여 검사를 실시하였다. 검사 자는 저자로부터 검사 실시 전에 검사목적과 검사절차에 대한 사 전 교육을 받았으며, 실제 검사절차에 대한 시연을 통해서 검사 과 정을 충분히 익힌 후 검사를 실시하였다. 검사자는 아동의 부모 및 교사로부터 사전동의를 얻은 아동을 대상으로 가정, 교회, 사교육 기관에 직접 방문하여 조용한 장소에서 개별적인 검사를 진행하였 다. 검사절차는 순서 효과를 최소화하기 위해 어휘 검사와 형태소 인식 검사순서를 바꿔서 배치하였다.

각 집단의 형태소인식 검사 원점수에 대한 집단적 차이를 검증하 기 위해 일원분산분석을 실시하였고, 집단 간 차이가 나타난 경우 Scheffé 사후 검정을 실시하여 집단 간 차이가 어떤 집단에서 비롯 된 것인지를 확인하였다. 또한 단어유형(합성어, 파생어)과 투명도 에 따라 집단 간 상호작용 효과가 있는지 알아보기 위해 반복측정 이원 분산분석을 실시하였으며, 차이가 있을 경우 Scheffé 사후 검 정을 실시하였다.
Table 2. Total scores of morphological awareness by group

\begin{tabular}{lccc}
\hline Group & T-MA & $F$ & Scheffe' \\
\hline VD (N=14) & $52.64(10.16)$ & $10.536^{*}$ & VD $=\mathrm{VL}<\mathrm{CA}$ \\
$\mathrm{VL}(\mathrm{N}=14)$ & $43.71(19.28)$ & & \\
$\mathrm{CA}(\mathrm{N}=14)$ & $66.50(7.11)$ & & \\
Total $(\mathrm{N}=42)$ & $54.29(2.47)$ & & \\
\hline
\end{tabular}

Values are presented as mean (SD).

$\mathrm{VD}=$ Vocabulary developmental Delay group; $\mathrm{CA}=$ Chronological Age matching group; $\mathrm{VL}=$ Vocabulary Level matching group. ${ }^{*} p<.05$.

\section{연구결과}

\section{세 집단별 형태소인식능력의 차이}

어휘발달지체 위험군 아동집단과 생활연령, 어휘수준을 일치시킨 세 집단아동의 형태소인식능력 검사결과는 Table 2에 제시하였다.

세 집단별 형태소인식능력 총점은 생활연령일치 아동집단, 어휘 발달지체 위험군 아동집단, 어휘수준일치 아동집단 순으로 평균 점수가 높게 나타났다. 세 집단 간의 차이를 알아보기 위해 일원분 산분석 검정으로 사후검정을 실시한 결과 집단 간 차이가 유의하게 나타났다. 이 차이는 생활연령일치 집단과 어휘발달지체 위험군 집 단 $(p=.030)$ 과 생활연령일치 집단과 어휘수준일치 집단 간 $(p=.00)$ 에서 유의하게 나타났으며, 어휘발달지체 위험군 집단과 어휘수준 일치 집단 간차이 $(p=.216)$ 는 유의하지 않았다.

\section{단어유형에 따른 형태소인식능력의 차이}

단어유형에 따른 형태소인식능력의 세 집단 간 차이에 대한 기술 통계 결과는 Table 3 과 같다.

단어 유형에 따른 집단 간 차이에 대한 통계적 유의성을 확인하기 위해 반복측정 이원분산분석을 실시한 결과 집단간 주효과 $\left(F_{(2,39)}=\right.$ $10.536, p<.05)$ 와 단어유형에 따른주효과 $\left(F_{(2,39)}=85.906, p<.05\right)$ 가 유의하게 나타났으나 상호작용효과는 유의하지 않았다 $\left(F_{(2,39)}=\right.$ $1.684, p>$.05). 사후검정 결과 생활연령일치 집단과 두 집단 간 차이 가 유의하였으며 $(p<.05)$. 어휘발달지체 위험군과 어휘수준일치 집 
Table 3. Descriptive statistics of scores on morphological awareness according to word type

\begin{tabular}{llc}
\hline Group & \multicolumn{1}{c}{ CW } & DW \\
\hline $\operatorname{VD}(\mathrm{N}=14)$ & $30.04(4.95)$ & $22.57(6.02)$ \\
$\operatorname{VL}(\mathrm{N}=14)$ & $24.71(10.61)$ & $19.00(9.32)$ \\
$\mathrm{CA}(\mathrm{N}=14)$ & $35.57(3.11)$ & $30.93(4.34)$ \\
Total $(\mathrm{N}=42)$ & $30.12(8.16)$ & $24.17(8.40)$ \\
\hline
\end{tabular}

Values are presented as mean (SD).

$\mathrm{VD}=$ Vocabulary developmental Delay group; $\mathrm{CA}=$ Chronological Age matching group; $\mathrm{VL}=$ Vocabulary Level matching group; $\mathrm{CW}=$ Compound Word; $\mathrm{DW}=$ Derivative Word.

단 간차이( $p>.05)$ 는 유의하지 않았다.

\section{투명도에 따른 형태소인식능력의 차이}

투명도에 따른 형태소인식능력의 세 집단 간 차이에 대한 기술통 계 결과는 Table 4 와같다.

투명도에 따른 집단 간차이에 대한 통계적 유의성을 확인하기 위 해 반복측정 이원분산분석을 실시한 결과 집단 간 주효과 $\left(F_{(2,39)}=\right.$ $10.536, p<.05)$ 와 단어유형에 따른 주효과 $\left(F_{(2,39)}=63.466, p<.05\right)$ 가 유의하게 나타났다. 하지만 집단과 투명도에 대한 상호작용효과 는 유의하지 않았다 $\left(F_{(2,39)}=1.198, p>\right.$.05). 집단에 대한 사후검정 결 과 생활연령일치 집단과 두 집단 간 차이가 유의하였으며 $(p=.000$, $p=.030)$, 어휘발달지체 위험군과 어휘수준일치 집단 간 차이는 유 의하지 않았다 $(p=.216)$.

\section{논의 및 결론}

이 연구는 초등 3 학년 어휘발달지체 위험군 아동과 생활연령, 어 휘수준을 일치시킨 아동을 대상으로 전체적인 형태소인식능력의 차이를 살펴보고, 단어유형(합성어, 파생어)과 투명도에 따른 집단 간수행력의 차이가 있는지를 알아보았다.

연구결과 어휘발달지체 위험군 아동집단과 생활연령 및 어휘수 준을 일치시킨 세 집단 아동의 형태소인식능력이 유의한 차이가 났 다. 이 차이는 생활연령일치 아동집단과 나머지 두 집단 간 차이에 서 비롯되었으며, 어휘발달지체 위험군 아동집단과 어휘수준일치 아동집단 간의 차이는 유의하지 않았다. 이러한 연구결과는 생활 연령의 차이에도 불구하고 이해 어휘량이 유사한 두 집단 아동들 이 형태소인식과제에서 역시 유사한 수행력을 보이고 있음을 나타 내는 것이다. 즉, 형태소인식능력이 어휘능력과 밀접한 관련이 있음 을 시사해주는 결과이다. 이는 초등 1,2 학년 아동을 어휘 수준에 따라 상위, 중위, 하위 수준으로 나눠 형태소인식능력의 차이가 있
Table 4. Descriptive statistics of scores on morphological awareness according to transparency

\begin{tabular}{lll}
\hline Group & \multicolumn{1}{c}{ Trans } & Non-trans \\
\hline VD $(\mathrm{N}=14)$ & $28.79(4.32)$ & $23.86(6.47)$ \\
VL $(\mathrm{N}=14)$ & $24.93(9.38)$ & $18.79(10.53)$ \\
$\mathrm{CA}(\mathrm{N}=14)$ & $35.14(3.44)$ & $31.36(4.01)$ \\
Total $(\mathrm{N}=42)$ & $29.62(7.46)$ & $24.67(9.00)$ \\
\hline
\end{tabular}

Values are presented as mean (SD).

$\mathrm{VD}=$ Vocabulary developmental Delay group; $\mathrm{CA}=$ Chronological Age matching group; $\mathrm{VL}=$ Vocabulary Level matching group; Trans= Transparency; Non-Trans= Non-Transparency.

는지를 살펴본 Chung (2017)의 연구에서 상위와 하위 집단 간 유 의한 차이가 났다는 연구결과와도 유사하다. 또한 어휘수준이 낮 은 아동에게 형태소 관련 어휘 중재를 실시한 후 사후 평가하였을 때 하위 수준 아동들이 상위 수준 아동과 어휘량의 차이가 줄고, 또래규준의 평균 범위 내로 향상되었음을 보고한 Ramirez 등(2013) 의 연구결과와 유사하게 형태소인식능력과 어휘능력 간의 높은 관 련성을 보여준 것으로 해석할 수 있다. 본 연구에서 어휘발달수준 을 일치시킨 아동들은 어휘발달지체 위험군 아동들에 비해 약 2 년 정도 생활연령의 차이가 나는 아동들로 모두 초등 1 학년 아동들이 었다. 이들은 학교 교과과정에 대한 노출 양이 상대적으로 적은 아 동들이지만 어휘량이 유사한 초등 3학년이 어휘발달지체 위험군 아동들과 형태소인식과제 수행력에 차이가 없는 것으로 연구결과 드러났다. 이는 형태소 분석 및 조작 기술의 정도와 어휘 습득량이 밀접한 관련이 있다는 가설을 입증해주는 결과이다.

다음으로 단어유형(합성어, 파생어)에 따른 형태소인식능력의 차이를 살펴본 결과 합성어와 파생어에 대한 형태소인식능력 간 차 이가 통계적으로 유의했으나 집단과 단어유형과의 상호작용 효과 는 유의하지 않은 것으로 나타났다. 즉 세 집단 모두 합성어를 파생 어보다 더 잘 인식하고 있으며 세 집단이 모두 유사한 패턴을 보이 는 것으로 나타났다. 이는 읽기학습부진 아동과 일반 아동을 대상 으로 파생어와 합성어 과제에서의 형태소인식능력의 차이를 살펴 본 Kim, S.와 Jung (2015)의 연구결과와도 유사하다. Kim, S.와 Jung (2015)의 연구에서 역시 파생어보다 합성어 과제의 수행력이 높았 고, 두 집단의 과제 수행 패턴도 유사한 것으로 나타났는데, 연구자 들은 의미가 분명한 어근과 어근을 분리 또는 합성하는 과제가 의 미가 명료하지 않은 접사가 포함된 파생어 과제보다 인지적 부담이 더 적기 때문이라고 해석하였다. 이는 익숙한 단어로 구성된 어근 을 결합하는 과제보다는 노출빈도가 낮은 접사에 대한 인식능력이 발달적으로 늦게 나타난다는 선행연구를 지지해주는 결과이다 (Goodwin, Lipsky, \& Ahn, 2012). 합성어의 경우 익숙한 단어의 형 
태인 어근 단위로 분절하고 결합하는 과제이고, 파생어는 익숙한 어근과 '헛'과 같이 상대적으로 비친숙한 접사를 조작하는 과제로 구성되어 있다. 아동들이 텍스트에서 복합어를 만났을 때 형태소 단위로 분절하고 익숙한 형태소는 총체적으로 처리하여 어휘사전 에 빠르게 접근하여 처리하고 비친숙한 형태소는 분리 처리하여 어 휘사전에 접근한다는 확장 설명된 형태론 모델(augmented address morphology)에 근거하여 해석해 볼 때 비친숙한 접사 처리가 더 어 려운 과제임을 본 연구결과에서도 보여주고 있다.

마지막으로 투명도에 따른 형태소인식능력의 차이를 살펴본 결 과, 투명도에 대한 주효과가 유의하였으나 집단과 투명도 간 상호작 용 효과는 유의하지 않은 것으로 나타났다. 즉 세 집단 모두 투명한 과제를 불투명한 과제보다 더 잘 인식하고 있으며 세 집단이 모두 유사한 패턴을 보이는 것으로 나타났다. 이는 학습부진 아동집단, 다문화가정 아동집단이 불투명한 다형태소 단어 과제를 더 어려워 한다는 선행연구 결과를 지지해 주는 결과이다(Kim, E., \& Jung, 2015; Kim, S., \& Jung, 2015). 투명도가 높은 과제는 형태소의 분절 경계가 음운적으로나 표기적으로도 명확하게 드러나기 때문에 형 태소가 좀더 쉽게 분절되고 결합되는 조작과정이 용이하여 인지적 처리 과정의 부담이 적었을 것이다.

한편 본 연구는 부모나 교사 보고에 의해 발달상의 문제가 없거 나 낱말 해독 능력의 제한이 없는 아동으로 통제하기는 하였으나 어휘 및 형태소인식능력에 관련이 높은 인지 기능에 대한 통제가 충분히 이루어지지 않아 해석상 주의가 필요하다. 추후 지능 및 생 태환경적 환경 요인을 통제하여 어휘와 형태소인식능력 간의 관계 를 살펴볼 필요가 있겠다. 또한 어휘와 형태소인식능력 간의 상호 적 인과관계를 밝혀줄 수 있는 연구 설계에 근거하여 두 변인 간 상 호 인과관계를 규명해줄 수 있는 후속연구도 필요하며, 형태소인식 능력이 어휘사전에 접근하는 방식을 보다 효과적으로 설명해줄 수 있는 모델에 대한 검증 연구 역시 지속적으로 이루어질 필요가 있다.

\section{REFERENCES}

Anglin, J. M. (1993). Vocabulary development: a morphological analysis. Monographs of the Society for Research in Child Development, 58(10), 1-166.

Apel, K., Diehm, E., \& Apel, L. (2013). Using multiple measures of morphological awareness to assess its relation to reading. Topics in Language Disorders, 33(1), 42-56.

Apel, K., Wilson-Fowler, E. B., Brimo, D., \& Perrin, N. A. (2012). Metalinguistic contributions to reading and spelling in second and third grade students. Reading and Writing, 25(6), 1283-1305.
Berko, J. (1958). The child learning of English morphology. Word, 14(2-3), 150-177.

Berninger, V. W., Abbott, R. D., Nagy, W., \& Carlisle, J. (2010). Growth in phonological, orthographic, and morphological awareness in grades 1 to 6 . Journal of Psycholinguistic Research, 39(2), 141-163.

Biemiller, A., \& Boote, C. (2006). An effective method for building vocabulary in primary grades. Journal of Educational Psychology, 98(1). 44-62.

Bowers, P. N., \& Kirby, J. R. (2010). Effects of morphological instruction on vocabulary acquisition. Reading and Writing, 80(20), 144-179.

Brimo, D. (2016). Evaluating the effectiveness of a morphological awareness intervention: a pilot study. Communication Disorders Quarterly, 38(1), 3545.

Carlisle, J. F. (2000). Awareness of the structure and meaning of morphologically complex words: impact on reading. Reading and Writing, 12(3), 169190.

Carlisle, J. F. (2004). Morphological processes that influence learning to read. In A. Stone, E. R. Silliman, B, Ehren, \& K. Apel (Eds.). Handbook of language and literacy: Development and Disorders (pp. 318-339). New york, NY: Guilford Press.

Chall, J. S. (1983). Stages of reading development. New York: McGraw-Hill.

Chialant, D., \& Caramazza, A. (1995). Where is morphology and how is it processed? The case of written word recognition. In L. B. Feldman (Ed). Morphological aspects of language processing. Hillsdale, NJ: Lawrence Erlbaum Association.

Chung, B. J. (2017). Relations between morphological awareness and vocabulary in first and second grades. Journal of Learner-Centered Curriculum and Instruction, 17(9). 541-562.

Chung, B. J., \& Shim, S. E. (2019). The realtion of morphological awareness, vocabulary, syntactic knowledge, reading and reading comprehension in 1st through 4th grades: inflection and derivation. Journal of Speech-Language \& Hearing Disorders, 28(3), 51-59.

Farsi, D. A. (2008). Morphological awareness and its relationship to vocabulary knowledge and morphological complexity among Omani EFL University students (Master's thesis), Queensland University, Brisbane, Austria, Australia.

Goodwin, A., Lipsky, M., \& Ahn, S. (2012). Word detective using units of meaning to support literacy. The Reading Teacher, 65(7), 461-470.

Jung, K. (2014). Morphological awareness and reading ability of school-aged children from grades 1 to 3. Communication Sciences and Disorders, 19(1), 21-30. 
Kyunghee Jung • Morphological Awareness of children with Vocabulary Development Delay

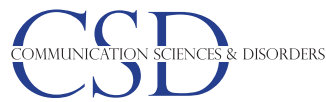

Kim, A. H. (2013). A comparison of elementary students with reading disabilities to students without disabilities on vocabulary performance and error patterns. The Korea Journal of Learning Disabilities, 10(1), 51-67.

Kim, E. H., \& Jung, K. H. (2015). Morphological awareness of 1st to 3rd grade school-aged children from multicultural families. Communication Sciences and Disorders, 20(2), 319-330.

Kim, S. H., \& Jung, K. H. (2015). Morphological awareness and reading abilities for early elementary school students with poor reading skill. Journal of Speech-Language \& Hearing Disorders, 24(2), 35-47.

Kim, Y. T., Hong, K. H., Kim, K. H., Jang, H., \& Lee, J. (2009). Receptive \& expressive vocabulary test (REVT). Seoul: Seoul Community Rehabilitation Center.

Kirby, J. R., Deacon, S. H., Bowers, P. N., Izenberg, L., Wade-Woolley, L., \& Parrila, R. (2012). Children's morphological awareness and reading ability. Reading and Writing, 25(2), 389-410.

Kuo, L. J., \& Anderson, R. C. (2006). Morphological awareness and learning to read: a cross-language perspective. Educational Psychologist, 41(3), 161180.

Mackey, E. J., Levesque, K., \& Deacon, S. H. (2017). Unexpected poor comprehenders: an investigation of multiple aspects of morphological awareness. Journal of Research in Reading, 40(2), 125-138.

McBRIDE-CHANG, C. McBRIDE-CHANG, C., Wagner, R. K., Muse, A., Chow, B. W. Y., \& Shu, H. U. A. (2005). The role of morphological awareness in children's vocabulary acquisition in English. Applied Psycholinguistics, 26(3), 415-435.

Nagy, W. E., \& Anderson, R. C. (1984). How many words are there in printed school English? Reading Research Quarterly, 19(3), 304-330.

Nagy, W. E., Herman, P. A., \& Anderson, R. C. (1985). Learning words from context. Reading Research Quarterly, 20, 233-253.

Pae, S., Kim, M., Yoon, H., \& Jahng, S. (2015). Korean Language-Based Reading Assessment. Seoul: Hakjisa.

Ramirez, G., Walton, P., \& Roberts, W. (2013). Morphological awareness and vocabulary development among kindergarteners with different ability levels. Journal of Learning Disabilities, 47(1), 54-64.

Scott, J. A., \& Nagy, W. E. (2004). Developing word consciousness. In J. F. Baumann, \& E. J. Kameenui (Eds.). Vocabulary instruction: research to practice (pp. 201-217). New york, NY: Guilford Press.

Sparks, E., \& Deacon, S. H. (2012). Morphological awareness and vocabulary acquisition: a longitudinal examination of their relationship in Englishspeaking children. Applied Psycholinguistic, 36(2), 299-321.

Stanovich, K. E. (2009). Mathew effects in reading: some consequences of individual differences in the acquisition of literacy. Journal of Education, 189 (1-2), 23-55.

Tong, X., Deacon, S. H., Kirby, J., Cain, K., \& Parrila, R. (2011). Morphological awareness: a key to understanding poor reading comprehension in English. Journal of Educational Psycjology, 103(3), 523-534.

Wagner, R. K., Muse, A. E., \& Tannenbaum, K. (2007). Promising avenues for better understanding implications of vocabulary development for reading comprehension. In R. Wagner, A. Muse, \& K. Tannenbaum (Eds.). Vocabulary acquisitio: implications for reading comprehension (pp. 276-292). New york, NY: Guilford Press.

Wolter, J. A., \& Green, L. (2013). Morphological awareness intervention and school-age language and literacy deficits: a case study. Topics in Language Disorders, 33(1), 27-41.

Wysocki, K., \& Jenkins, J. R. (1987). Deriving word meanings through morphological generalization. Reading Research Quarterly, 22, 66-81. 


\section{국문초록}

\section{초등 3학년 어휘발달지체 위험군 아동의 형태소인식능력 \\ 정경희}

용인대학교 재활복지대학원 언어치료학과

배경 및 목적: 형태소인식능력은 텍스트에서 접하는 새로운 어휘의 의미에 접근하기 위해 효율적으로 단어를 사용하게 하는 메타언어 능력으로 언어, 읽기 및 쓰기 습득과정에 주요한 기술이다. 본 연구는 학령기 아동의 형태소인식능력을 어휘발달 수준과 관련해서 살펴 보고자 한다. 방법: 연구대상은 초등하교 3 학년 어휘발달지체 위험군 아동 14 명, 이 아동과 생활연령 및 어휘수준을 일치시킨 아동 각 14 명으로 총 42 명의 아동이 연구에 참여하였다. 연구과제는 선행연구를 바탕으로 단어의 유형(합성어, 파생어)과 투명도를 고려하여 개발된 형태소인식능력 과제를 사용하였다. 결과: 연구결과는 첫째, 형태소인식능력의 총점은 세 집단 간 유의한 차이가 있었으며, 어 휘발달지체 위험군과 어휘수준을 일치시킨 아동 집단 사이에서는 차이가 없었으나 어휘수준이 다른 집단들 사이에서는 유의하게 차 이가 나타났다. 둘째, 세 집단 모두 파생어에 대한 과제 수행력이 낮았다. 합성어 과제에서는 어휘수준일치집단과 어휘발달지체 위험군 아동 간 유의한 차이가 없었으나 파생어에서는 유의한 차이가 나타났다. 셋째, 투명도에 따른 집단 간 차이와 투명도 여부에 따른 차이 가 통계적으로 유의하게 나타났다. 두 가지 과제 모두 어휘발달지체 위험군 아동과 어휘수준일치 아동 집단 간 차이가 유의하였으나생 활연령일치 아동과 두 집단에서는 유의한 차이가 있었다. 논의 및 결론: 본 연구결과 어휘발달 수준과 형태소인식능력 사이의 밀접한 관련이 있음을 알 수 있었으며, 학령 초기 어휘평가 및 중재에서 형태소인식능력과의 관계를 고려해야함을 시사해주었다.

핵심어: 형태소인식능력, 어휘, 합성어, 파생어, 투명도

이 논문은 2017년 한국연구재단의 지원을 받아 수행한 연구임(NRF-2017S1A5A8021586).

\section{참고문헌}

김순호, 정경희(2015). 초등저학년 읽기학습부진아동의 형태소인식과 읽기능력. 언어치료연구, 24(2), 35-47.

김영태, 홍경훈, 김경희, 장혜성, 이주연(2009). 수용·표현어휘력검사(REVT). 서울: 서울장애인종합복지관.

김은하, 정경희(2015). 초등 1-3학년 다문화가정 아동의 형태소인식능력. Communication Sciences and Disorders, 20(2), 319-330.

김애화(2013). 초등학교 읽기장애학생과 일반학생의 어휘 특성 및 오류 유형 비교 연구. 학습장애연구, 10(1), 51-67.

배소영, 김미배, 윤효진, 장승민(2015). 한국어읽기검사(KOLRA). 서울:학지사.

정경희(2014). 1-3학년 학령기 아동의 형태소 인식과 읽기능력. Communication Sciences and Disorders, 19(1), 21-30.

정부자(2017). 초등학교 1-2학년 아동의 어휘력에 따른 형태인식 특성. 학습자중심교과교육연구, 19(9), 541-552.

정부자, 심승은(2019). 초등 1-4학년 아동의 형태인식 유형에 따른 어휘, 구문 및 읽기 특성. 언어치료연구, 28(3), 51-59.

\section{ORCID}

정경희(제1저자, 교신저자, 교수 https://orcid.org/0000-0002-1816-0171) 